\title{
Malaysian and Indonesian Learners: They are Judges of How They Learn English Most Effectively in and out of Classrooms
}

\author{
Nur Huslinda Dato' Che Mat' ${ }^{1}$, Laila Ulsi Qodriani², M. Yuseano Kardiansyah³, \\ Nor Sukor Ali ${ }^{4}$, Pauziah Mat Hassan ${ }^{5}$ \\ nurhuslinda@salam.uitm.edu.my ${ }^{1}$, ani.teknokrat@yahoo.com² ${ }^{2}$ useano@yahoo.com ${ }^{3}$, \\ norsukorali@polisas.edu.my ${ }^{4}$, pmathassan@ gmail $^{5}$ \\ Universiti Teknologi Mara (UiTM) Shah Alam Selangor Malaysia ${ }^{1}$, \\ STBA Teknokrat Lampung Indonesia ${ }^{2,3}$, POLISAS Kuantan Pahang Malaysia ${ }^{4}$
}

\begin{abstract}
The position of English is that of a Second Language in Malaysia and a Foreign Language in Indonesia. But the objective is the same that is to enable the learners to communicate effectively and efficiently in social and professional situations. Learners' beliefs and learners' strategies are also part of the learning processes. Strategies are ways of managing the complex information that the learners are receiving about the target language. This study aims to find out (i) the learners' beliefs on the importance of English (ii) what the learners will do (strategies) to manage their own learning. 100 respondents participated in the study. They responded to open ended questions. The results show that there are similarities and differences in the ways the Malaysian and Indonesian learners perceived the importance of English. They also have similarities and differences in their strategies to manage their own learning to achieve their goals. As a conclusion, even though the two countries adopted different language policy, the learners of English as a Second and Foreign Language have their own enthusiasms and they make judgements about how to learn the language effectively and they have the awareness of what language learning is like.
\end{abstract}

Key Words: learner's beliefs, learner's strategies

\section{Introduction}

\section{The Background}

Someone once said 'In one sense, all students are different, in another sense, all students are the same' (Wallace, 1991). Tutors and teachers will no doubt read their own meanings into this rather enigmatic remark, but most tutors would probably agree, from their own experience and observation, that different students certainly learn in different ways (Wallace, 1991: 20).Main (1980:10) in Wallace (1991) summarises the different types of students: 'Syllabus-bound students needs exams in order to study, do not read widely outside the set work, attend classes regularly and may very well have conscientious study habits, while 'the syllabus-free students, on the other hand, 'operate better when they can pursue their own lines of work, and often feel restricted by course requirements'. Fortunately, nowadays, all course descriptions to be much more explicit in stating exactly what is to be expected of students and how they will be graded. Criteria for assignments and examinations, for example, tend to be more explicit and public (Wallace, 1990).

This study is related to the discovering how students would tackle the task of learning English either as a second language or as a foreign language, that is, how they perceived the importance of English and what they will do to improve themselves in the four language skills : listening, speaking, reading and writing. The subjects of this study consist of students of ESL from Malaysia and students of EFL from Indonesia. The respondents from Indonesia were students of Akademi Manajemen Informatika dan Komputer (AMIK) Teknokrat, Lampung, Indonesia. The status of English for them is as a Foreign Language. The main objective of learning English in their Institution for this group of students is to enhance their knowledge of English for Business. It is designed to enable students to understand words and expressions and the concepts used in business. It is transferred through both theory and practice. The students are also taught to focus on Soft Skills Attributes which are mainly disciplined, creative, critical, analytical, logic, initiative, confident, and cooperative. As for the standard competences, the students are expected to be able to practice their English skills both written and oral in doing business activities. For the learning strategy, students are encouraged to get involved in pair and group discussions. They are asked to discuss some vocabularies in the passage. As for the lecture, the lecturer gives some theory and explanation related 
to the topic to be discussed. There are also question and answer session whereby the lecturer gives some questions relating to the passage or paragraph and the students answer the questions. As for the assessment, they are based on Quiz, (10\%) Mid test, (20\%), assignment (30\%) and final examination (40\%).

However, the respondents from Malaysia consist of a group of students from Universiti Teknologi Mara (UiTM). As for the UiTM ESL learners, their English course is designed to build the listening, reading, speaking and writing skills to help them perform effectively and competently in the social and academic contexts. This is done through the integration of the language skills. The course focuses on enhancing the students' abilities to use the language by exploiting a variety of materials in varied situations. Appropriate consideration is given to the development of higher-level grammatical construction, vocabulary expansion and extensive reading activities which are intended to increase students' lexical density. The grammar items are taught incidentally in reading, listening, speaking and writing: parts of speech, subject-verb agreement, noun-pronoun agreement, verb tenses, Yes/No and WH Questions, transitional words and phrases, clauses and passive voice. As for the assessment, it is based on an on-going assessment with 15\% for Speaking, 10\% for Listening Test , 20\% Mid Term Test, 15\% Online Assignments and 40\% Final Exam.

From the given background, students are expected to achieve a certain level of proficiency. Teaching is conducted based on the syllabus specifications, schemes of work, teaching materials with some suggested approaches, techniques, activities and the creativities of the instructors. However different learners achieve different grades and proficiency levels. According to Chamot (1987:83) “ $\ldots$ second or foreign language learners are not mere sponge acquiring the new language by osmosis alone. They are thinking, reflective beings who consciously apply mental strategies to learning situations both in the classrooms and outside it."

In learning English as a second or as a foreign language, the learners should have the awareness of selfdirected learning. Some learners depend so much on their instructors. Some of them do not see the importance of learning the language. Thus, the study focuses on the following research questions such as (1) What are the ESL and EFL learners' perceptions/beliefs towards the importance of English language? (2) What are the ESL and EFL learners' strategies (planning) to improve their English? (3) What are the similarities and the differences among ESL and EFL learners' perceptions and strategies in language learning? In order to produce a competitive new generation that is marketable locally and abroad, one area that needs urgent attention is the mastery of the English Language. Students in higher learning institutions need to be trained to become efficient or self-efficacy learners who are competent and effective. Students must be taught how to plan, how to monitor and how to evaluate their own work to overcome their ESL/EFL learning difficulties.

\section{Theory and Method}

For this study, the researchers used the concepts from O'Malley et al.(1985), Nisbets and Schucksmith (1986), Oxford (1990) and Rubin and Thompson (1994) where Metacognitive Strategies are summarised as " higher order thinking or executive skills which enable students to approach learning in a systematic, efficient and effective way by using the elements of Planning, Monitoring and Evaluating". With respect to this study the focus is directly on Planning, but indirectly they involve monitoring and evaluating.

\section{Respondents}

The respondents of this study were students in higher learning institutions from Malaysia and Indonesia. They are considered compatible because they are of the same age, that is, 18-19years old). Respondents from Malaysia consist of 50 students from UiTM. Respondents from Indonesia are 50 students from AMIK Teknokrat, Lampung, Indonesia. The selection was based on purposive sampling.

\section{Data Collections and Data Analyses}

The respondents were given two questions. They responded in a written report. The first question is "Describe why English is important to you?".The second question is "What will you do to improve your English?"

The students' responses were collected and analysed. The data were listed and tabulated into various themes and categories. The responses would be presented as quantitative data as well as qualitative data. The quantitative data were obtained through frequency counts and then converted into percentages as shown in various tables below. Some examples of the qualitative data would be presented as vignettes. 


\section{Literature Review}

Second language learners as well as foreign language learners often hold different beliefs or notions about language learning, some of which are influenced by students' previous experiences as language learners, and others that are shaped by their own cultural backgrounds as well as the language policy adopted (Horwitz,1987). In her review of representative studies based on her questionnaire, BALLI (Beliefs about Language Learning Inventory), Horwitz pointed out that individual differences, such as age, stage of life, learning style, educational experiences, and learning circumstances, including instructional levels, family, language learning contexts, likely account for as much variation as cultural differences. Based on the assumption that individual differences and learning circumstances likely account for as much variation as cultural differences, the researcher decided to conduct the present study to investigate and understand the ESL and EFL students perceptions or beliefs about the importance of learning the English language in their own context (Horwitz,1987). Research on beliefs about language learning also has proven that learners' beliefs may have the potential to influence both their experiences and actions as language learners, and there are links between beliefs, motivation, and strategy use (Abraham and Vann, 1987; Horwitz, 1988; Wenden 1986, 1987; Yang, 1999). As to the research on relationships between learners' beliefs and language learning strategies, many researchers have provided direct or indirect evidences on the connection between these two variables. Wenden (1986) found that students could not only distinctly describe their beliefs about language learning but also adopt consistent learning strategies, and she also indicated that these learners' explicit beliefs about how best to learn a language seemed to provide the logic for their choice of learning strategies. Horwitz (1988) argued that some preconceived beliefs are likely to restrict learners' range of strategy use. Abraham and Vann (1987) also suggested that learner's beliefs about how language operates and, consequently, how it is learned may affect the variety and flexibility of strategy use.

Learners' perceptions of their own strengths and weaknesses as language learners can influence their use of opportunities available for language learning and the priorities they set for themselves (Richards \& Lockhart, 1999:56). Myers (1981) conducted a study on the use of strategies among successful learners, and concluded that successful ESL learners are learners with a sense that they are competent and effective and are aware of their learning strategies and why they employ the strategies (p. 417). Ellis and Sinclair (1989) conducted a study and the finding was consistent with that of Myers. They generalise that good language learners are 'self-aware' and that they are aware of and understand the reasons for their attitudes and feelings towards language learning (p.6). A study was conducted by Ag. Bambang et al. (1999) in Indonesia and found that successful and unsuccessful learners do employ learning strategies in their ESL/EFL learning. Mac Leod (2002) found that successful learners employed a wide range of learning strategies as compared to the less successful learners. Furthermore, it has been noted that successful learners develop insights into beliefs about language learning processes, their own abilities and the use of effective learning strategies (Oxford, 1990). Therefore, awareness of learners' beliefs is central to teaching, and while some may have a facilitative effect on learning, others can hinder the learning process and contributes to anxiety. So far, research has established that learners' perceptions and beliefs are shaped by their own attitudes. There is more to be said about this as Ellis and Sinclair (1989) quoted that teachers and learners are partners in learning. The teacher is the language learning 'expert' and the learner is the 'expert' in him or herself. Thus, studies into beliefs about language learning provided insights into their role on acquisition. It was revealed that attitudes to learning and the perceptions and beliefs that determine them may have a profound influence on learning behaviour (Bandura, 1986) and on learning outcomes (Nyikos \& Oxford, 1987).

\section{Results}

This section presents ESL and EFL learners' perception and beliefs towards the importance of the English language as well as the EFL and EFL learners' strategies to improve their English. The results are presented quantitatively and qualitatively.

\section{Results from Quantitative Data}

Table 1: Indonesian EFL Learners' Perceptions Towards the Importance of English

\begin{tabular}{|cl|c|c|}
\hline 1. & International communication & 38 & $76 \%$ \\
\hline 2. Job Application & 30 & $60 \%$ \\
\hline 3. & Further Education & 8 & $16 \%$ \\
\hline 4. & Making Friends & 2 & $4 \%$ \\
\hline 5. & Other English Activities & 2 & $4 \%$ \\
\hline
\end{tabular}




\begin{tabular}{|c|c|c|}
\hline 6. $\quad$ Networking & 2 & $4 \%$ \\
\hline 7. Electronic Use & 2 & $4 \%$ \\
\hline 8. General Knowledge & 2 & $4 \%$ \\
\hline 9. $\quad$ Skills & 2 & $4 \%$ \\
\hline
\end{tabular}

Table 1 shows how the Indonesian EFL learners perceived the importance of English. There are 9 categories mentioned by the learners. The first category which is the highest rank is that English is important for international communication and $76 \%$ of the learners are in this category. $60 \%$ or almost two thirds of the learners perceived that English is important for their job application and their future careers. However, less than a quarter or 16\% of them learn the language for further education. Other than these, the Indonesian EFL learners perceived the importance of English for making friends (4\%), for other English activities (4\%), for networking (4\%), for electronic use (4\%), for general knowledge (4\%) and for skills acquisition (4\%) respectively.

Table 2 : Malaysian ESL Learners' Perceptions Towards the importance of English

\begin{tabular}{|c|c|c|}
\hline 1. International communication & 48 & $96 \%$ \\
\hline 2. Jobs application /Job Interviews/ future career & 40 & $80 \%$ \\
\hline 3. Further study overseas/abroad & 30 & $60 \%$ \\
\hline 4. To facilitate learning of difficult subjects/MUET \& IELT & 20 & $40 \%$ \\
\hline 5. Travelling/tour/vacation in other countries & 13 & $26 \%$ \\
\hline 6. Presentation/meetings abroad & 11 & $22 \%$ \\
\hline 7. Share knowledge, get information from internet & 9 & $18 \%$ \\
\hline 8. $\quad$ Research/reference books & 6 & $12 \%$ \\
\hline
\end{tabular}

Table 2 shows how Malaysian ESL learners perceived the importance of English. There are 8 categories mentioned by the learners. The first category, a large majority (96\%) believed that English is important for international communication. $80 \%$ believed that it is for their job application or for future careers. Almost two thirds or 60\% perceived that English is important to further their studies overseas. Another $40 \%$ thinks that it is to facilitate their learning of difficult subjects/ MUET (Malaysian University English Test) and IELT (International English Language Test). Slightly more than a quarter (26\%) seems to perceive the importance of English for travelling or tour round the world or going for vacation. Slightly more than a fifth $(22 \%)$ believed that English is important for presentation or attending meetings abroad later on. $18 \%$ believed that it is for sharing of knowledge, or getting information from the internet. However a small percentage (12\%) believed that it is important for research and also to understand reference books.

Table 3: Indonesian EFL Learners Strategies (Planning) to Improve their English

\begin{tabular}{|rl|c|c|}
\hline 1. & Self-study/ self-monitoring & 29 & $58 \%$ \\
\hline 2. & Vocabulary enrichment & 25 & $50 \%$ \\
\hline 3. & Speak / Practice using the language & 23 & $46 \%$ \\
\hline 4. & Listen to English news /songs & 20 & $40 \%$ \\
\hline 5. & Watching English movies & 15 & $30 \%$ \\
\hline 6. & Pair \&Group discussions & 13 & $26 \%$ \\
\hline 7. & Attending English Courses & 10 & $20 \%$ \\
\hline 8. & Sing English songs & 8 & $16 \%$ \\
\hline 9. & Write and send emails & 6 & $12 \%$ \\
\hline 10. Reading English materials & 2 & $4 \%$ \\
\hline
\end{tabular}

Table 3 shows what the Indonesian EFL learners would do to improve their English in their own context. There are 10 categories mentioned by the learners. Slightly more than half or $58 \%$ of the respondents believed that self-study is effective for them in order to improve their English. A half or 50\% believed that they can improve themselves by doing vocabulary enrichment. Slightly less than a half (46) believed that they can improve their English by practising using the language. Slightly more than a third (40\%) believed that they can improve their English by listening to English news or English songs. The rest believed that they can improve their English by watching English movies (30\%), pair and group discussion (26\%), attending courses (20\%), sing English songs (16\%), write and send emails to friends (12\%) and reading English materials which is 4\% only. 
Table 4: Malaysian ESL Learners Strategies (Planning) to improve their English

\begin{tabular}{|c|c|c|}
\hline 1. Read English materials(newspapers, magazines, books, novels, etc) & 40 & $80 \%$ \\
\hline 2. Speak /communicate with people/group discussion & 30 & $60 \%$ \\
\hline 3. Refer dictionary/ vocabulary enrichment & 26 & $52 \%$ \\
\hline 4. Listen to English news/weather forecast/songs & 20 & $40 \%$ \\
\hline 5. Do Revisions/exercise/practice/tuition & 18 & $36 \%$ \\
\hline 6. Networking/correspondence/emails & 16 & $32 \%$ \\
\hline 7. Watching English movies & 15 & $30 \%$ \\
\hline 8. Attend class regularly/participate in all English activities & 13 & $26 \%$ \\
\hline 9. Write diary in English daily & 13 & $26 \%$ \\
\hline 10. Write story/poems & 10 & $20 \%$ \\
\hline 11. Always send SMS in English & 9 & $18 \%$ \\
\hline 12. Sing English songs & 9 & $18 \%$ \\
\hline 13. Always communicate with tourists/foreigners & 5 & $10 \%$ \\
\hline 14. Reduce shyness & 3 & $6 \%$ \\
\hline
\end{tabular}

Table 4 shows how Malaysian (UiTM) ESL learners would do to improve their English. There are 14 categories mentioned by the learners. A high percentage that is $80 \%$ believed that they would improve their English through reading of English materials. 60\% or almost two thirds believed that they would improve their English by communicating with other people or always having group discussions. Slightly more than a half (52\%) would refer to dictionary for the enrichment of their vocabulary. $40 \%$ which is slightly less than a half would listen to English news or weather forecast or English songs to improve their English. A lower percentage, that is, slightly more than a third (36\%) would do revision, and exercise or language practice or attend tuition classes to improve their English. Slightly less than a third (32\%) believed that they can improve their English through networking, correspondence or writing and sending of emails. 30\% believed that they may improve by watching English movies. Slightly more than a quarter (26\%) believed that they can improve if they attend English class regularly and participate in all English activities. The same percentage goes for writing diary in English daily. A group of learners (20\%) believed that they can improve if they always write a story or poems. Interestingly, a group of learners (18\%) believed that they can improve their English if they always send SMS in English and the same percentage goes for singing in English songs. 10\% believed that they can improve their English if they always communicate with tourists or foreigners. $8 \%$ prefer to write poems in order to improve their English. A small percentage $(6 \%)$ believed that they can perform well in English if they reduce their shyness.

\section{Results from Qualitative data}

Below are vignettes which were taken from the respondents' report. These are their perceptions and beliefs about the importance of learning English language and what they will do or plan to do to improve their English.

\section{ESL.1/uitm/2013}

"English is important to me because it has many advantages. Firstly it will qualify me to study abroad in the UK or Australia. Secondly I will be able to communicate with confidence and most importantly it is for my future career."

"In order to improve my English, I have to attend my English class and fulfil the course requirement. I have to read a lot of English reading materials and always refer to dictionary for meanings of difficult words and always converse with people in English."

\section{ESL 2/uitm/2013}

"English is important to me because it will determine my goal to further my study overseas. It is to prepare myself for a good job after graduation. I love reading blogs from the websites to gain knowledge and information and being good in English is an asset."

"There are many ways to improve my English. I love reading English newspapers as well as listening to English news, weather reports and songs helps me a lot. I also write my diary daily in English and would check for words from the dictionary to enrich my vocabulary".

\section{ESL3/uitm/2013}

"English is important to me because it will help me to communicate well locally and abroad. I need to achieve the highest band in MUET and IELT to qualify me to study abroad." 
"In order to improve my English, I would try to read more, listen more to English news and English songs. In order to enrich my vocabulary, I like to refer to dictionary for new words."

\section{ESL4/uitm/2013}

"English is important to me because it will help me get a good job in a multi-national company. It enhances my communication with people around the world."

"To improve my English I have to attend my English class regularly. I have to use the language with friends and lecturers."

\section{ESL5/uitm/2013}

"English is important to me because it is a way to be recognised as a successful person to enter university abroad and later to obtain a degree and secure a good job."

"I will try to improve my English. The first thing that I would like to do is to speak, listen, write and read more in English as well as watching more of English movies and less of Malay dramas.

\section{ESL6/uitm/2013}

"English is important to me because I would like to further my study abroad and as an international student, it will enhance my communication with students and lecturers over there." activities".

"In order for me to improve my English, I have to attend lectures regularly and participate in all English

\section{ESL7/uitm/2013}

"English is important to me to prepare myself for job application. It will enhance me to attend meetings abroad or in my presentation later on."

"I think the best way to improve myself is to read a lot and also to check the dictionary for meanngs of difficult words".

\section{ESL8 /uitm/2013}

"English is important as it will help me understand and gather information from internet. It helps me to get through with job interviews later on."

"The things that I will do to improve myself is to read more English materials, to listen more to English news and to watch more of English movies."

\section{ESL9/uitm/2013}

"English is important to me because that will secure me a place in a university abroad. It is for my international communication".

"In order to improve my English, I have to use the language daily. I always feel shy to speak to people around me. So, I have to reduce my shyness".

\section{ESL10/uitm/2013}

"English is important to me because I can use it for my international communication. I love travelling and I can communicate with tourists also. I have the intention to study overseas, so I have to get good results for my MUET. I must practice using the language".

"I think I can improve my English if I am more focused in my work. I have to read more of English texts, speak English at all times with friends, listen to English songs, news, and also write and send sms in English to contacts".

\section{EFL 11/amik/2013}

"In order for me to get a good job after I complete my study, I have to be good in English. It makes me feel more confident to communicate with people. English is important for a brighter future". language”.

"Practice makes perfect. So, that is my way of improving myself in this language. I must always use the

\section{$\underline{\text { EFL 12/amik/2013 }}$}

"English is important to me because I can use it for international communication. I have the intention to further my education abroad and I can easily make friends with other students from other countries." myself better."

"In order for me to improve my English, I have to do vocabulary enrichment. In this way I can express 


\section{EFL 13/amik/2013}

English is important to me because it is for my future career. It is for my job application. When I finish studying I will apply for a job.

I believe that I can improve my English if I always use the language. Another way to improve my English is by listening to English songs. It can help me improve my pronunciation.

\section{EFL 14/amik/2013}

English is important to me because it is a language of the computer. I like to surf the internet to get information and general knowledge. I can understand better if my English is better and better.

I think I can improve my English by doing self-study. During my free time, I study on my own to improve my English. There are many websites which offer online learning. I make use of these facilities.

\section{EFL 15/amik/2013}

English is important to me because it is an international language. One day I want to further my education abroad and if my English is good, I will not face problem in my study there.

There are ways that I can improve my English. I usually listen to English songs and watch movies (that contains English) in order to be familiar with English. I do these because I love them, so that I can learn English from things that I love.

\section{EFL 16/amik/2013}

English is important. Nowadays, people learn English for international communication and for networking.Since I was junior high school, I've been encouraged to go to the English course. I think this activity has been helping me a lot to improve my English.

\section{EFL 16/amik/2013}

To me English is a very important subject. If my English is good, it helps me in my job application. I always dream about going somewhere far away from my homeland to work and get recognition. So, English will help to make my dream comes true.

To improve my English, I can read English books such as English stories, English text book, \& English dictionary. From that, I can enrich my vocabulary \& gained more knowledge about English by myself.

\section{EFL 17/amik/2013}

We cannot deny that English is important to us. It is the language of the computer. People all over the world use the language to communicate with one another. It is for international communication.

To improve my ability in speaking English, I force myself to practice speaking English with some people such as teachers, friends, \& native speakers.

\section{EFL 18/amik/2013}

English is important for international communication. I like to get myself involve with English activities. I like to surf the internet for information as well as for general knowledge.

Usually my frien and I would do pair or group discussions to improve our English. Together, we can share and discuss how to improve our English with one another.

\section{EFL 19/amik/2013}

English is important to me for international communication. This is an era where internet is a common way of communicating with people around the world. Another useful electronic device is hand-phone. We can talk to anyone around the world.

In order to improve my English, I can do a kind of self-monitoring activity, for example recording my speech and evaluate my English speaking ability. In order for me to write better, I think I can improve my English if I write and send emails to my friends regularly.

\section{EFL 20/amik/2013}

English is important to me. Some of my friends who are good in this language they get better results and they study better. I believe if I am good in English I will improve in my study too. English is important for my future career.

I often ask my teacher about my English ability and also request suggestion how to improve my English. I like to listen to English news or English songs and I think this is one of the ways to improve my English. 


\section{Discussion and Conclusion}

This study was carried out with the purpose of making more visible of the ways in which ESL learners may be similar or different from EFL learners within their own contexts in terms of their perceptions and their beliefs in learning the English language. They are the best judge of their own learning habits in and outside their classrooms. The results as shown in Table 1 and Table 2, show that there are some similarities and differences in the categories mentioned by both groups of learners regarding the importance of English to them. The first and second categories seem to be similar. Both groups, that it, the Malaysian ESL learners and the Indonesian EFL learners perceived that English is important for international communication, job application and for further studies. Although they differ in the percentages, the top three rankings are similar. Therefore from here it is obvious that although the language policy is different, the learners from both countries seem to know best as to why English is important to them.

As for Table 3 and Table 4, there are some similarities and differences in the categories mentioned by both groups of learners regarding the ways they chose to improve their English. As for the Malaysian ESL learners, the top three categories preferred by the learners are reading English materials, speak or communicate with people and vocabulary enrichment and followed by the rest. As for the Indonesian EFL learners, the top three categories preferred by them are self-study or self-monitoring, vocabulary enrichment and speak or practice using the language and followed by the rest. Although they differ in the first category, they are similar with vocabulary enrichment and speak and communicate with people. However, from the result, a real contrast category is on reading the English materials. The results show that $80 \%$ of the Malaysian ESL learners mentioned that they will improve their English if they read more of English materials. This category gained the highest rank among Malaysian ESL learners. However only $4 \%$ of Indonesian EFL learners believed that this activity will improve their English. This category gained the lowest rank among the Indonesian EFL learners. This is an interesting finding which needs a further research as to why the majority of the Malaysian EFL learners prefer reading as the best way to improve their English and in contrast, the majority of the Indonesian EFL learners do not believe that reading English materials will improve their English.

Overall, from the results, it could be seen how different learners have different perceptions and beliefs and attitudes towards the important of English. They also have their own individual ways of learning to improve their English language. As a conclusion, even though the two countries adopted different language policy, the learners of English as a Second and Foreign Language have their own enthusiasms and they make judgements about how to learn the language effectively and they have the awareness of what language learning is like. The good learners always know what is best for them.

\section{Pedagogical Implication of the Study}

Firstly, the instructors will understand better regarding the learners' perceptions and beliefs about the important of English and the various ways that they think they can improve their English. Hence it is appropriate for the instructors to encourage the learners to learn effectively and at the same time providing them effective instructions of the effective strategies. Secondly, learners should be encouraged to think strategically about their own learning and encourage them to work independently. Finally, the instructors should encourage the learners to develop positive beliefs which will lead to effective learning and to give them more opportunities to evaluate more of their own work in order to encourage them to become independent learners.

\section{References}

Abraham, R. G., \& Vann, R. J. (1987). Strategies of two language learners: A case study. In Wenden and Rubin (Eds.), Learner strategies in language learning. Englewood Cliffs, NJ: Prentice-Hall.

Ag. Bambang Setiyadi, Lloyd Holliday and Ray Lewis (1999). A survey of language learning strategies in a tertiary EFL in Indonesia. ERIC Clearinghouse on Information Resources Syracuse NY.

Bandura, A. (1986). Self-foundation of thought and action. A social cognitive theory. Englewood Cliffs, NJ: Prentice-Hall.

Chamot, A.U. (1987) The learning strategies of ESL students. In A. Wenden \& J. Rubin (Eds.). Learner Strategies in Language Learning. Cambridge: Prentice-Hall. 71-84. 
Chamot, A. and O'Malley, J.M. (1994). Implementing the cognitive academic language learning approach (CALLA). In R. Oxford (Ed.), Language learning strategies around the world: Cross Cultural acquisition in bilingual pre-school programs. TESOL Quarterly, 17, 401-419.

Chang, C.Y. (2003). The effects of language learning motivation on the use of language learning strategies among EFL learners at technological universities and colleges in Taiwan. Unpublished doctoral dissertation, Spalding University, Kentucky, USA.

Cohen, A. (1987). Studying learner strategies: how we get the information, in A. Wenden and J.Rubin (eds.), Learner strategies in language learning, London: Prentice Hall International.

Corno,L. and Mandinach, E.B. (1983). The role of cognitive engagement in classroom learning and Motivation. Educational Psychologist, 18 (2), 88-108.

Ellis, R. (1997). Second language acquisition. Oxford: Oxford University Press.

Ellis, G. and Sinclair,B. (1989). Learning to learn English. Cambridge: Cambridge University Press.

Horwitz, E.K. (1987). Surveying student beliefs about language teaming. In A. L. Wenden \& J. Robin (Eds.), Learner strategies in language learning (pp. 119-132). London: Prentice Hall.

Horwitz, E. K. (1988). The beliefs about language learning of beginning university foreign language students. Modern Language Journal, 72, 283-294.

Lin, C.Y. (2004). A Study on Administering English Education Policies of Elementary School. The Journal of School Administrators, 34, 150-163。

Liu, Min-ling (2004). A Study of Beliefs about Language Learning and Learning Strategies of Senior High School Students. Unpublished Master's Thesis, National Kaohsiung Normal University.

MacLeod, P. (2001). A case study of the learning strategies of two successful learners of English as a second language with instrumental motivation. Journal of Language and Linguistics. Vol.1 No.2, 2002.ISSN 1475-8989.

McKeachie, W. J. (1988). The need for study strategy training. In C. E. Weinstein, E. T. Goetz, \& P. A. Alexander (Eds.), Learning and study strategies: Issues in assessment, instruction, and evaluation (pp. 3-9). New York: Academic Press.

Mills, N., Pajares, F., and C. Herron. (2007) Self -efficacy of College Intermediate French Students: Relation to achievement and motivation. Language Learning. Vol.57, Iss.3 pg.417

Myers, P.J. (1981). Learning strategies: An overview. In Weistein, C.E. Goetz \& P. Alexander (Eds.), Learning and study strategies: Issues in Assessment, instruction, and evaluation. New York: Academic Press.

Nisbet, J. and Schucksmith, J. (1986).Learning Strategies. Boston, Mass: Routledge and Kegan Paul.

Nyikos, M. and Oxford, R. (1987). Strategies for foreign language learning and second language acquisition. Paper presented at the conference on Second Language Acquisition and Foreign Language Learning, University of Illinois, Champaign-Urbana.

O'Malley, J.M., Chamot, A.U., and Walker, C. (1987). Some applications of cognitive theory to second language acquisition. Studies in Second Language Acquisition, 9287-306.O’Malley, J.M., Chamot, A.U., StewnerManzanares, G., Kupper, L., and

Russo, R.P. (1985). Learning strategies used by beginning and intermediate ESL students. Language Learning, 35, 21-46. et al, 1985a,

Oxford, R.L. (1990). Language Learning Strategies: What Every Teacher Should Know. Englewood Cliffs, NJ: Newbury House.

Oxford, R. L., \& Nyikos, M. (1989). Variables affecting choice of language learning strategies by university students. Modern Language Journal, 73, 291-300. 
Richards, J. C. and Lockhart, C. (1996). Reflective teaching in second language classrooms. Cambridge: Cambridge University Press.

Rubin, J. (1975). What the "good language learner" can teach us. TESOL Quarterly, 9, 41-51.

Rubin, J. and Thompson I.(1994). How to be a more successful language learner.2nd ed. Boston: Heinle and Heinle.

Siebert, L. (2003). Student and teacher beliefs about language learning. Foreign Language Annals, 33, 394-420

Vann, R. and Abraham, R. (1990). Strategies of successful language learners. TESOL Quarterly 24, 2: 177-198.

Wallace, M.J. (1991). Training foreign language teachers. A reflective approach. Cambridge:

Cambridge University Press.

Wenden, A. L. (1986). Helping language learners think about learning. English Language Teaching Journal, 40, 201-215.

Wenden, A. L. (1987). Conceptual background and utility. In A. L. Wenden \& J. Rubin (Eds.), Learner Strategies in Language Learning (pp. 3-13). Englewood Cliffs. NJ: Prentice-Hall.

Yang, N.D. (1992) Second language learners' beliefs about language learning and their use of learning strategies: A study of college students of English in Taiwan. Unpublished doctoral dissertation, University of Texas, Austin, TX.

Yang, N. D. (1993). Beliefs about language learning and learning strategy use: A study of college students of English in Taiwan. Papers from the tenth conference on English teaching and learning in the Republic of China, 193-219.

Zimmerman B.J. and Martinez-Pons, M. (1990). Student differences in self-regulated learning: Relating grade, sex, and giftedness to self-efficacy and strategy use. Journal of Educational Psychology, 82(1), 51-59. 